\title{
PENGARUH STRATEGI POSITIONING MUSEUM TERHADAP KUNJUNGAN WISATA EDUKASI DI KOTA BANDUNG (SURVEY SEGMEN PASAR GENERASI Y)
}

\author{
Vanessa Gaffar \\ Manajemen Pemasaran Pariwisata FPIPS UPI
}

\begin{abstract}
Bandung has many heritage buildings and museums that can be very attractive to tourists. Nowadays, many heritage buildings, especially museums are developed to cater the needs of students and youngster to improve their knowledge. Hence, visiting museum and many other heritage buildings become activities in edu-tourism. Youngster and students are those in the segment of Genration Y that are targeted by museum. The characteristics of Gen-Y is that they like something new and very update with the newes technology. This Characteristic are really on the opposite sites of the appearance of museum that contains history and heritage of the past. Hence, the museums as a heritage objects should develop good positioning strategy in attracting those segment. This research focus on the evaluation of positioning strategy that is implemented by some museums in Bandung city and its influence to the decision making in visiting edu-tourism sites. The dimensions of positioning strategy consist of value, uniquenessm credibility, sustainability, and suitability. The result shows that the positioning strategy has significant influence to the tourist decision making The most significant value is on the "sustainability" or the preference tendency of a museum to be exist in the long term.
\end{abstract}

Keywords: Museum, Edu-tourism, Positioning Strategy, Generation Y.

\section{PENDAHULUAN}

\subsection{Latar Belakang}

Salah satu tujuan dari pengembangan pariwisata di dunia adalah konservasi atau pelestarian budaya dan sejarah yang ada di masyarakat. Konservasi dan preservasi budaya memiliki manfaat yang sangat dalam, utamanya dalam meningkatkan jati diri suatu bangsa dan berkaitan erat dalam memajukan pendidikan bagi masyarakat luas. Salah satu bentuk dari pengembangan kepariwisataan yang berkaitan dengan konservasi dan pelestarian budaya adalah melalui pengembangan atraksi wisata bersejarah (heritage).

Sejarah merupakan unsur dan nilai yang membedakan antara satu destinasi dengan destinasi yang lain yang membentuk keunggulan bersaing suatu destinasi pariwisata. Sebagai contoh, salah satu hal yang paling membedakan antara Kota Bandung dengan kota-kota lain di Indonesia maupun kota lain di dunia internasional adalah sejarah beserta peninggalan sejarah yang ada didalamnya.

Kondisi ini menjadikan sejarah menjadi salah satu distinctive value yang khas dari suatu destinasi yang dapat dioptimalkan untuk menjadi suatu asset dalam pengembangan pariwisata. Wisata bersejarah (heritage tourism) mampu menarik wisatawan mancaegara (wisman) maupun wisatawan nusantara (wisnus). Bagi wisman, khususnya yang memiliki keterkaitan sejarah dengan suatu kota tertentu, wisata bersejarah menarik dikunjungi untuk bernostalgia atau mempelajari identitas suatu kota.

Wisnus menyukai wisata bersejarah lebih memaknai jati diri bangsanya dan sebagai salah satu upaya dalam meningkatkan pengetahuan yang lebih dalam mengenai bangsanya. Dengan demikian, maka muatan edukasi/pendidikan sangat kuat dalam pengembangan kegiatan wisata bersejarah ini.

Kota Bandung adalah salah satu kota yang memiliki potensi yang tinggi untuk dikembangkan menjadi kawasan wisata bersejarah dengan koleksi bangunan lama dan museum yang cukup memadai. Secara garis besar tujuan museum adalah digunakan sebagai sarana pendidikan masyarakat (community education), apresiasi terhadap nilai budaya (cultural appreciation), dan menikmati kegiatan yang ada didalamnya (enjoyment).

Kunjungan ke museum di Jawa Barat, khususnya kota Bandung juga mengalami peningkatan, khususnya bagi wisatawan pelajar. Kegiatan yang dilakukan di museum adalah untuk menambah pengetahuan sehingga aktivitas wisata yang dilakukan sangat berkaitan erat dengan wisata edukasi.

Adapun definisi dari wisata edukasi yang diadopsi dari Australian Capital Tourism (2004) adalah kegiatan perjalanan yang dilakukan oleh wisatawan yang berusia 15 tahun ke atas dengan tujuan utama untuk 
pendidikan (education) dan lama tinggal kurang dari 12 bulan.

Dalam konteks segmentasi pasar berdasarkan aspek demografis, pelajar tergolong dalam segmen generasi $Y$, yaitu golongan sekelompok orang yang lahir dari tahun 1978 sampai dengan tahun 1994yang memiliki karakteristik yang unik karena tingkat kuriositi dan preferensi terhadap sejarah mulai terkikis.

Selama ini, museum identik dengan tempat yang menghadirkan masa lalu, sangat berbeda dengan karakteristik segmen generasi $\mathrm{Y}$, yang lebih menyukai sesuatu yang bersentuhan dengan teknologi dan aspek kekinian dalam berwisata

Berdasarkan hal tersebut, menarik untuk dikaji topik penelitian tentang bagaimana Strategi Positioning Museum Terhadap Kunjungan Wisata Edukasi Di Kota Bandung (Survey Segmen Pasar Generasi Y).

\subsection{Rumusan Masalah}

Berdasarkan latar belakang, maka rumusan masalah dalam penelitian ini adalah sebagai berikut:

1. Mengetahui gambaranstrategi positioning museum di Kota Bandung;

2. Mengetahui gambaran keputusan wisatawan dari segmen pasar generasi $\mathrm{Y}$ untuk melakukan wisata edukasi di Kota Bandung Bandung;

3. Mengetahui pengaruh strategi positioning wisata bersejarah terhadap keputusan berwisata edukasi di Kota Bandung

\subsection{Tujuan Penelitian}

Sesuai dengan latar belakang penelitian yang telah dikemukakan sebelumnya, maka tujuan dari penelitian ini adalah untuk memperoleh beberapa temuan, yaitu berupa:

1. Gambarantentangstrategi positioning museum di Kota Bandung;

2. Gambaran keputusan wisatawan dari segmen pasar generasi Y untuk melakukan wisata edukasi di Kota Bandung Bandung;

3. Sejauh mana pengaruh strategi positioning wisata bersejarah terhadap keputusan berwisata edukasi di Kota Bandung

\section{KAJIAN PUSTAKA}

\subsection{Wisata Bersejarah dan Museum}

Wisata bersejarah (heritage tourism) adalah kegiatan wisata yang dilakukan ditempat-tempat peninggalan bersejarah seperti museum, candi, petilasan, dan lain sebagainya sehingga wisatawan semakin memaknai sejarah daerah yang dikunjunginya.
Salah satu obyek wisata bersejarah adalah museum, yang biasanya merupakan organisasi yang bersifat nirlaba, yang bertujuan untuk mengkoleksi, konservasi, dan memberikan pendidikan kepada masyarakat, sehingga produk dan layanan yangdiberikan termasuk dalam bentuk public good. Pendanaan dan pengelolaan museum diberikan oleh pemerintah, walaupun beberapa museum mencari dukungan dana atau investasi dari masyarakat dan sponsor lainnya (Museum Australia, 2007).

Museum merupakan suatu badan tetap, tidak tergantung kepada siapa pemiliknya melainkan harus tetap ada. Museum bukan hanya merupakan tempat kesenangan, tetapi juga untuk kepentingan studi dan penelitian. Museum terbuka untuk umum dan kehadiran serta fungsi-fungsi museum adalah untuk kepentingan dan kemajuan masyarakat.

Menurut para ahli permuseuman dalam International Council of Museum (ICOM) di Copenhagen pada tahun 1974 membuat rumusan tentang museum yaitu: sebuah lembaga yang bersifat permanen, melayani kepentingan masyarakat dan kemajuannya, terbuka untuk umum, tidak bertujuan mencari keuntungan yang mengumpulkan, memelihara, meneliti, memamerkan, dan mengkomunikasikan benda-benda pembuktian material manusia dan lingkungannya, untuk tujuan-tujuan studi, pendidikan, dan rekreasi (FFJ Schouten, Pengantar Didaktik Museum, Jakarta, Proyek Pembinaan permuseuman, Ditjen Kebudayaaan, 1992: 3).

Museum dalam kaitanya dengan warisan budaya adalah lembaga, tempat penyimpanan, perawatan, pengamanan, dan pemanfaatan benda-benda bukti materiil hasil budaya manusia serta alam dan lingkungannya guna menunjang upaya perlindungan dan pelestarian kekayaan budaya bangsa (Pasal 1 . (1). PP. No. 19 Tahun 1995). Namun museum dalam kaitannya dengan ilmu pengetahuan dan kebudayaan pada umumnya mempunyai arti yang sangat luas.

Koleksi museum merupakan bahan atau obyek penelitian ilmiah. Museum bertugas mengadakan, melengkapi dan mengembangkan tersedianya obyek penelitian ilmiah itu bagi siapapun yang membutuhkan. Selain itu museum bertugas menyediakan sarana untuk kegiatan penelitian tersebut bagi siapapun, di samping museum bertugas melaksanakan kegiatan penelitian itu sendiri dan menyebar luaskan hasil penelitian tersebut untuk pengembangan ilmu pengetahuan umumnya. 
Adapun kegiatan yang dapat dilakukan di museum meliputi:

1. Pameran atau eksebisi produk dan koleksi museum, yang meliputi:

a. Pameran tetap (permanen), kegiatan penyajian koleksi berdasarkan sistem dan tahun.

b. Pameran khusus (temporer atau non permanen), kegiatan penyajian koleksi dalam jangka waktu relatif singkat (1 minggu sampai 1 bulan) dengan tema khusus.

c. Pameran keliling, kegiatan penyajian koleksi dalam jangka waktu tertentu dengan tema khusus serta dilakukan di luar lokasi museum.

2. Perpustakaan, menyediakan dan meminjamkan buku, majalah serta melayani peminat microfis, film yang berkaitan dengan benda-benda koleksi museum beserta sejarah keterangannya.

3. Kegiatan Edukatif, yang meliputi:

a. Ceramah, memperkenalkan koleksi museum kepada khalayak ramai dengan cara penyampaian yang mudah dimengerti oleh masyarakat umum.

b. Pemutaran film, penyajian audiovisual yang memperjelas pengetahuan mengenai benda-benda koleksi museum serta sejarah yang berkaitan dengan benda-benda koleksi tersebut.

c. Pemutaran film, penyajian audiovisual yang memperjelas pengetahuan mengenai benda-benda koleksi museum serta sejarah yang berkaitan dengan benda-benda koleksi tersebut.

d. Bimbingan edukatif, memberikan data dan penjelasan yang dibutuhkan oleh para peneliti yang bergerak di bidang yang berhubungan dengan koleksi museum.

Klasifikasi museum dapat dikategorikan ke dalam beberapa jenis, antara lain:

1. Berdasarkan penyelenggaraannya:

a. Museum Swasta, yaitu museum yang diselenggarakan dan dikelola oleh swasta.

b. Museum resmi, yaitu museum yang diselenggarakan dan dikelola oleh pemerintah. Museum dalam klasifikasi ini terbagi lagi menjadi museum yang dikelola oleh pemerintah daerah dan pemerintah pusat.

2. Berdasarkan kedudukannya:

- Museum Nasional, yang menjadi urusan pemerintah yang menggambarkan harta warisan sejarah dan kebudayaan nasional.

- Museum Lokal, terbagi menjadi museum dengan ruang lingkup tingkat provinsi, kabupaten, dan kotamadya.

- Museum Lapangan Terbuka, terletak di luar ruangan dapat merupakan suatu kompleks yang luas, seperti Taman Mini, terdiri dari model-model rumah adat, baik yang asli, dan yang telah berpindah tempat dari asal daerahnya semula, maupun tiruan sebagai koleksi pelengkap.

3. Berdasarkan jenis koleksi, meliputi:

- Museum khusus, museum jenis ini memiliki koleksi penunjang satu cabang ilmu pengetahuan saja, misalnya Museum Geologim Museum Seni Rupa, Museum Teknologi, dan lain sebagainya.

- Museum umum, museum jenis ini memiliki koleksi penunjang cabangcabang ilmu pengetahuan alam, teknologi, dan ilmu pengetahuan sosial.

4. Berdasaran jenis bangunan:

- Museum terbuka, penyajian koleksi dilakukan secara terbuka.

- Museum tertutup, penyajian koleksi dilakukan secara tertutup.

- Kombinasi, penyajian koleksi disajikan secara kombinasi antara museum terbuka dan tertutup.

\subsection{Wisata Edukasi}

Beberapa definisi dan pengertian dari wisata edukasi adalah sebagai berikut:

1. Australian Capital Tourism (2004) mendefinisikan wisata edukasi sebagai kegiatan perjalanan yang dilakukan oleh wisatawan yang berusia 15 tahun ke atas dengan tujuan utama untuk pendidikan (education) dan lama tinggal kurang dari 12 bulan.

2. Rodger (1998:28) mendefinisikan wisata edukasi sebagai "program in which participants travel to a location as a group with the primary purpose of engaging in a learning experience directly related to the location" (Rodger, 1998, p. 28). Kegiatan yang dilakukan meliputi ecotourism, heritage tourism, rural/farm tourism, and student exchanges between educational institutions.

Pertumbuhan perjalanan untuk kegiatan pendidikan bukan merupakan hal baru (Gibson, 1998; Holdnak \& Holland, 1996; Kalinowski \& Weiler, 1992) dan tingkat popularitasnya untuk semakin bertumbuh diharapkan 
mengalami peningkatan (Gibson, 1998; Holdnak \& Holland, 1996).

Pada perkembangannya, museum juga dijadikan sebagai daya tarik wisata, dan untuk lebih dikenal luas oleh masyarakat maka perlu dilakukan kegiatan pemasaran. Namun, karena museum memiliki dimensi sosial sebagai pusat edukasi masyarakat, maka perlu dicermati untuk mengembangkan strategi pemasaran yang dapat menyeimbangkan fungsi sosial dari museum tersebut.

\subsection{Strategi Positioning}

Strategi positioning merupakan tahap strategi pemasaran selanjutnya, setelah segmenting dan targeting. Positioning merupakan cara pandang konsumen terhadap produk yang ditawarkan. "Product position is the way the product is defined by consumers on important attributes - the place the product occupies in consumer's mind relative to competing products" (Kotler, 2006:179). Selanjutnya dijelaskan bahwa posisi produk merupakan gabungan kompleks dari persepsi, impresi dan perasaan yang dimiliki konsumen terhadap suatu produk, dibandingkan dengan produk pesaing. Posisi produk pada benak konsumen terjadi dengan atau tanpa upaya pemasaran yang dilakukan perusahaan. Namun pemasar merencanakan posisi yang mampu memberikan keuntungan terbesar bagi produknya pada pasar sasaran yang dipilih, dan merancang bauran pemasaran untuk menciptakan posisi yang direncanakan tersebut.

Pendapat lain menurut Hermawan Kertajaya (2006:1) mengemukakanbahwa :Positioning merupakan upaya untuk mempengaruhi pikiran konsumen dengan penawaran perusahaan kita. Positioning strategi untuk mengarahkan pelanggan. Positioning adalah upaya membangun kepercayaan dimata konsumen bahwa produk kita memang layak dipercaya dan kompeten.

Pengertian Positioning menurut Freddy Rangkuti (2002:49) adalah suatu cara untuk menempatkan produk sehingga tertanam di dalam benak konsumen. Positioning yang tidak tepat dapat mengakibatkan produk atau jasa yang kita luncurkan akan dipersepsikan berbeda oleh konsumen, sedangkan Positioning yang tidak jelasakan mengakibatkan kekacauan persepsi di benak konsumen, yang akhirnya konsumen menjadi ragu-ragu untuk membelinya.

Kunci utama keberhasilan positioning terletak pada persepsi yang diciptakan. Selain ditentukan oleh persepsi pelanggannya sendiri, posisi atau citra sebuah perusahaan dipengaruhi pula oleh pesaing dan pelanggan mereka. Secara tradisional, positioning dimulai dari persepsi atau citra yang ingin ditampilkan produk atau perusahaan lalu diciptakanlah slogan atau pesan kampanye. Positioning haruslah dilakukan bertahap.

Penyegaran posisi merek merupakan jawaban terhadap seberapa jauh relevansinya dengan pasar sasaran, perubahan pelanggan, dinamika dan kecenderungan pasar, serta tujuan dan sasaran perusahaan. Menurut AB Susanto \& Himawan W $(2004 ; 154)$ ada lima prinsip yang dapat dipakai untuk melihat efektifitas positioning yaitu :

1. Nilai, terfokus pada manfaat yang diterima pelanggan. Intinya adalah nilai apa yang diterima oleh pasar sasaran dari posisi merek yang dimiliki perusahaan.

2. Keunikan, pada intinya membawa sesuatu yang tidak dimiliki oleh pesaing sehingga posisi merek perusahaan memberikan penawaran yang berbeda dibandingkan pesaing.

3. Kredibilitas, menunjukan seberapa besar kredibilitasnya di mata konsumen.

4. Berkelanjutan/Keberlanjutan, intinya memaksimalkan waktu rentang waktu lamanya menempati posisi dalam persaingan.

5. Kesesuaian. Yakni kesesuaian antara posisi merek dengan perusahaan.

\subsection{Proses Pengambilan Keputusan Berwisata}

Pengambilan keputusan berwisata mengadaptasi konsep pengambilan keputusan membeli. Keputusan tersebut timbul karena adanya penilaian objektif atau karena adanya dorongan emosi, keputusan untuk bertindak adalah hasil dari serangkaian aktifitas yang dapat dideskripsikan dalam proses pembelian.

Salah satu proses pengambilan keputusanBerdasarkan hal tersebut, dengan mendaptasi Kotler dan Keller (2006:500) tentang model AIDA, yaitu:

1. Attention, timbulnya perhatian konsumen terhadap suatu stimulus pemasaran yang dilakukan produsen, dalam hal ini tempat wisata

2. Interest, munculnya rasa ketertarikan terhadap objek yang ditawarkan produsen tersebut atau membangkitkan minat

3. Desire, setelah rasa tertarik, timbul hasrat atau keinginan untuk memiliki objek tersebut atau berkunjung

4. Action, tindakan konsumen pembelian yang dilakukan konsumen setelah memiliki 
hasrat atau keinginan untuk memiliki objek atau berkunjung ke suatu tempat wisata.

Berdasarkan kajian literatur tersebut, maka rerangka penelitian ini adalah sebagai berikut:

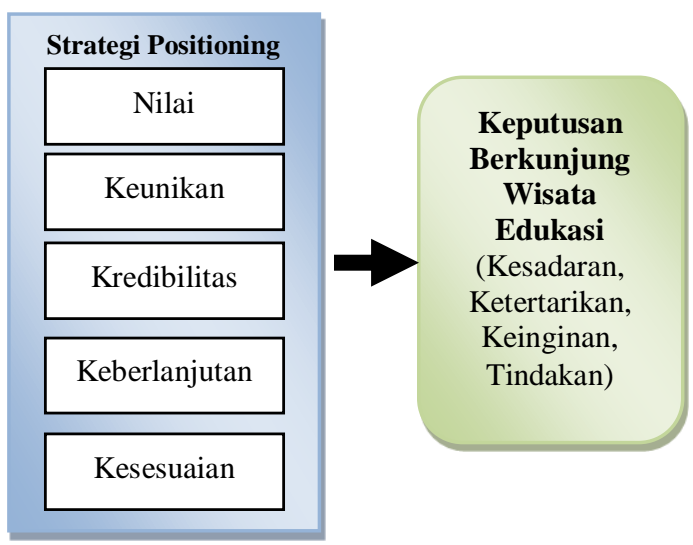

\section{GAMBAR 1}

PARADIGMA PENELITIAN

\section{METODE PENELITIAN}

Penelitian mengenai strategi positioningwisata bersejarah dalam meningkatan kunjungan berwisata edukasi di Kota Bandung menggunakan pendekatan manajemen pemasaran khususnya mengenai positioning sebagai variabel bebas (independent variabel), serta proses keputusan berkunjung sebagai variabel terikat (dependent variabel).

Variabel pertama adalah strategi positioning memiliki lima sub variable yaitu nilai, keunikan, kredibilitas, berkelanjutan, dan kesesuaian. Sedangkan yang menjadi variabel kedua adalah peningkatan kunjungan yang mengadopsi teori dan konsep keputusan pembelian yang terdiri dari tiga indikator yaitu, Kesadaran, Ketertarikan, Keinginan, dan Tindakan untuk mengunjungi museum.

Unit analisis dari penelitian ini adalah penyusun strategi positioning yaitu pengelola museum di Kota Bandung. Sedangkan unit observasi dalam penelitian ini adalah wisatawan dari segmen pasar Generasi Y yang berkunjung ke atraksi wisata bersejarah untuk tujuan edukasi di Kota Bandung. Mereka adalah pelajar setingkat SMP atau SMA yang berusia 15 tahun ke atas.

Penelitian ini mengambil sampel sebesar 300 responden di 7 museum yang berada di Kota Bandung, yaitu Museum Konferensi Asia Afrika, Museum Geologi, Museum Sri Baduga, Museum Mandala Wangsit, Museum Zoologi, Museum Pos
Indonesia, dan Museum Barli. Survey dilaksanakan pada periode September Oktober 2009.

\subsection{Teknik Analisis Data}

Teknik analisis data yang digunakan adalah Path Analysis dengan alat bantu SPSS 15.0. Dalam Hal ini jalur yang digunakan untuk menentukan besarnya variabel indipenden $(X 1$, $\mathrm{X} 2, \mathrm{X} 3, \mathrm{X} 4, \mathrm{X} 5)$ terhadap $\mathrm{Y}$ baik secara langsung maupun tidak langsung.

Selanjutnya struktur hubungan diata diterjemahkan kedalam hipotesis yang menyatakan pengaruh variable bebas yang dominan terhadap variabel terikat. Kriteria pengambilan keputusan pengujian hipotesis secara statistik dalam rangka pengambilan keputusan penerimaan atau penolakan hipotesis menurut Sugiyono (2005:188) adalah sebagai berikut:

1. Jika $\mathrm{t}$ hitung $>\mathrm{t}$ tabel, maka Ho ditolak dan Hi diterima

2. Jika $\mathrm{t}$ hitung $<\mathrm{t}$ tabel, maka Ho diterima dan Hi ditolak

Secara statistik hipotesis yang akan diuji berbeda pada taraf kesalahan 0,05 dengan derajat kebebasan (dk) (n-2) serta uji satu pihak, yaitu pihak kanan. Adapun Hipotesis penelitian ini adalah Strategi Positioning (X)berpengaruh terhadap Keputusan Berkunjung (Y), dengan Sub Hipotesis sebagai berikut:

- Nilai berpengaruh terhadap Keputusan Berkunjung

- Keunikan berpengaruh terhadap Keputusan Berkunjung

- Kredibilitas berpengaruh terhadap Keputusan Berkunjung

- Keberlanjutan berpengaruh terhadap Keputusan Berkunjung

- Kesesuaian berpengaruh terhadap Keputusan Berkunjung

\section{HASIL PENELITIAN DAN PEMBAHASAN}

4.1 Karakteristik Wisatawan

4.1.1 Usia

Mayoritas pengunjung museum berusia 15 - 17 tahun $(59 \%)$ atau pelajar setingkat SMA. Hal ini menunjukkan bahwa golongan generasi Y yang berkunjung ke museum relatif lebih besar dibandingkan yang lain, yaitu pengunjung yang berusia $18-20$ tahun $(21 \%)$ dan pengunjung yang berusia $12-14$ tahun $(20 \%)$. 


\subsubsection{Latar Belakang Pendidikan}

Pengunjung yang berasal dari SMA adalah sebesar 63\%, SMP 26\%, dan Universitas $11 \%$. Hal ini menunjukkan bahwa hasil penelitian ini secara rata-rata akan ditekankan pada analisa persepsi generasi Y yang berada pada tingkat pendidikan setaraf SMA.

\subsubsection{Gender}

Hasil penelitian menunjukkan bahwa pengunjung wanita $(56 \%)$ lebih besar dibandingkan dengan pengunjung laki-laki (44\%). Namun demikian, bukan berarti bahwa wanita lebih suka mengunjungi museum dibandingkan pria. Namun, perbedaan komposisi gender ini dihasilkan dari perolehan jumlah responden yang ditemui ketika survey dan perbedaan komposisi tersebut tidak terlalu signifikan. Dengan demikian, hasil penelitian mampu mengungkap secara seimbang dan obyektif antara penilaian yang bersifat feminim (wanita) dan maskulin (pria). Obyektifitas ini penting, khsusnya untuk menghasilkan generalisasi dari penilaian dan manfaat yang dapat diimplementasikan untuk referensi dalam pengelolaan museum.

\subsubsection{Kemampuan Finansial}

Dalam rangka mengetahui tingkat kemampuan finansial pengunjung generasi $\mathrm{Y}$ untuk datang ke museum secara individu, pada penelitian ini dikumpulkan informasi mengenai jumlah uang saku per hari.

Secara rata-rata, pengunjung memiliki uang saku di atas Rp. 15.000,- per hari (37\%), sekitar 34\% pengunjung memiliki uang saku Rp. 10.000,- sd Rp. 15.000,- per hari, dan sekitar 29\% memiliki uang saku sebesar Rp. 5.000,- sd Rp. 10.000,- per hari.

Angka ini menunjukkan bahwa pengunjung generasi $\mathrm{Y}$ secara finansial mampu mengunjungi museum di Kota Bandung secara individu (mandiri) karena rata-rata tiket masuk ke museum berkisar antara Rp. 1.000.- sd Rp. 10.000,- bahkan beberapa museum tidak memungut biaya masuk. Biaya yang dikeluarkan untuk mengunjungi museum selain tiket masuk adalah biaya transportasi, yang cukup terjangkau.

\subsubsection{Aktivitas Waktu Luang}

Selain meneliti tentang aspek finansial, dikumpulkan pula informasi mengenai hobi atau aktivitas pengunjung generasi $\mathrm{Y}$ yang dilakukan untuk mengisi waktu luang.

Hasil menunjukkan bahwa mayoritas pengunjung menyukai mendengarkan dan bermain musik (37\%) dan olahraga (32\%) untuk mengisi waktu senggangnya. Sebagian kecil (20\%) menyukai membaca dan melakukan kegiatan lainnya (11\%) yaitu rekreasi seperti menonton film, berbelanja, dan mengunjungi tempat-tempat wisata. Hal ini menunjukkan, bahwa kaum generasi Y lebih tertarik pada kegiatan seni dan olahraga untuk mengisi waktu senggangnya. Hal ini dapat dijadikan referensi bagi museum untuk menambahkan unsur seni dan olahraga dalam pengelolaannya.

\subsubsection{Penggunaan TIK}

Salah satu ciri-ciri khusus dari karakteristik generasi Y adalah kedekatan yang erat dengan teknologi informasi dan telekomunikasi melalui internet.

Data menunjukkan mayoritas pengunjung menggunakan internet $3-5$ jam perminggu (41\%) dan $5-8$ jam (22\%). Angka ini relatif kecil dibandingkan dengan konsumsi penggunaan internet bagi remaja di Inggris, dimana remaja, termasuk yang berusia 15 tahun ke atas, menghabiskan waktu selama 31 jam pe minggu dalam menggunakan internet (www.telegraph.com, diakses tanggal 20 November 2009). Penggunaan internet bagi remaja di Kota Bandung juga relatiif lebih kecil dari Malaysia. Data yang dihimpun oleh Omnicom Media Group, Malaysia pada tanggal 16 Mei 2008 menunjukkan bahwa remaja di Malaysia menghabiskan waktu selama 3.21 jam per hari untuk menggunakan internet atau sekitar 22,41 jam per minggu. Kebiasaan ini membuat membuat pengelolaan museum di beberapa negara mulai melibatkan internet untuk memperkenalkan museum kepada para remaja. Namun demikian, berdasarkan hasil penelitian, agaknya media internet belum dapat dijadikan sebagai salah satu metoda dalam pengelolaan museum di Kota Bandung. Namun demikian, berdasarkan informasi yang didapatkan dari Kepala Museum KAA, tersedianya layanan internet di perpustakaan museum cukup menarik minat pelajar di tingkat SMP dan SMA untuk berkunjung.

\subsubsection{Kesan terhadap Museum}

Daya tarik museum relatif cukup baik di mata para pengunjung generasi Y. Data berikut ini menunjukkan bahwa mayoritas pengunjung menganggap bahwa museum merupakan tempat yang menarik untuk dikunjungi $(57 \%)$.

Data tersebut juga menunjukkan bahwa sekitar 35\% pengunjung mengatakan bahwa museum merupakan tempat yang biasa-biasa saja dan jumlah tersebut tidak terlalu signifikan. Dengan demikian dapat disimpulkan bahwa pengunjung yang berasal dari generasi $\mathrm{Y}$ cukup tertarik untuk mengunjungi museum. 


\subsubsection{Tujuan Berkunjung}

Secara rata-rata pengunjung yang datang bertujuan untuk mencari data dalam rangka menyelesaikan tugas dari sekolah (50\%), study tour (38\%), dan hanya sebagian kecil yang mengunjungi museum untuk berekreasi. Hal tersebut menunjukkan bahwa alasan mengunjungi museum lebih banyak bersifat edukasi dibandingkan dengan alasan rekreasi. Hal ini semakin menguatkan fungsi museum pada masyarakat yaitu untuk mendiseminasikan pengetahuan secara luas.

Data tersebut menunjukkan bahwa unsur edukasi sangat dominan dalam kegiatan berwisata di museum. Namun demikian, unsur kesenangan (enjoyment) tetap dirasakan oleh pengunjung. Implikasinya, dalam pengelolaan museum tidak hanya dituntut untuk dapat memberikan informasi sedemikian rupa sehingga bermanfaat untuk menambah pengetahuan, tetapi perlu juga diperhatikan bagaimana mengemas museum menjadi tempat yang menarik dan menyenangkan sehingga pengunjung yang dapat dapat memiliki pengalaman yang berbeda selama menambah ilmu pengetahuan di museum.

\subsubsection{Frekuensi Kunjungan ke Museum}

Secara rata-rata, responden pernah mengunjungi museum di Kota Bandung sebanyak satu kali, walaupn ada sebagian kecil yang mengunjungi suatu museum sebanyak dua atau tiga kali. Hal ini menunjukkan bahwa pengunjung yang berasal dari generasi $Y$ secara rata-rata pernah berkunjung ke museum dan menjadi pasar sasaran dalam pengembangan museum.

Adapun museum yang paling sering dikunjungi adalah Museum Geologi, Museum KAA, dan Museum Sri Baduga. Sedangkan museum yang jarang dikunjungi adalah Museum Pos, Museum Mandala Wangsit, Museum Zoologi, dan Museum Barli.

Hal tersebut menunjukkan bahwa lokasi museum berpengaruh pada frekuensi kunjungan yang dilakukan. Museum Geologi, Museum KAA, dan Museum Sri Baduga relatif mudah untuk diakses karena terletak di jalur utama Kota Bandung. Adapun museum yang lain relatif sulit diakses, misalnya Museum Zoologi yang berada di dalam lingkungan Kebun Binatang Bandung, kecuali Museum Mandal Wangsit yang terletak di jalur yang cukup mudah diakses namun kurang dikunjungi.

\subsection{Persepsi Generasi Y Terhadap Positioning Museum di Kota Bandung}

Berikut ini akan dibahas mengenai persepsi pengunjung yang berasal dari generasi $\mathrm{Y}$ tentang strategi positioning museum. Bagian ini akan membahas cara yang dilakukan oleh pengelola museum dalam menempatkan keberadaan museum dalam benak pengunjung. Pendekatan yang digunakan untuk menelaah strategi positioning ini adalah pada eksplorasi sub variabel yang meliputi nilai, kredibilitas, keunikan, keberlanjutan, dan kesesuaian.

\subsubsection{Nilai}

Nilai dalam berkunjung ke museum adalah perbandingan antara manfaat dan korbanan yang dikeluarkan oleh seseorang ketika ia melakukan kunjungan ke museum. Apabila pengunjung merasakan bahwa manfaat yang didapatkan lebih besar dibandingkan dengan korbanan yang diberikan, maka nilai yang didapatkan akan semakin bermakna. Di lain pihak, apabila korbanan yang dikeluarkan saat melakukan kunjungan lebih besar dibandingkan manfaat yang diterima, maka kunjungan tersebut termasuk dalam kategori kurang bernilai.

Data menunjukkan bahwa secara ratarata pengunjung menganggap bahwa manfaat berkunjung ke museum lebih besar dibandingkan dengan korbanan yang dikeluarkan. Pemahaman ini diturunkan kedalam formula Manfaat $/$ Korbanan = Nilai $(\mathrm{N})$. Jika $\mathrm{N}<1$, maka nilai termasuk dalam kategori rendah, dan jika $\mathrm{N}=1$, berarti nilai yang dirasakan sedang, dan jika $\mathrm{N}>1$, berarti nilai yang dirasakan tinggi. Nilai skor rata-rata manfaat yang dirasakan oleh pengunjung adalah 1.117 (74\%) sedangkan nilai skor ratarata dari korbanan yang dikeluarkan adalah 947.25 (63\%) dengan demikian indeks nilai yang didapatkan adalah sebesar $1.18(\mathbf{N}=$ 1.18). Hal ini menunjukkan bahwa nilai yang didapatkan tergolong pada kategori "tinggi" karena berada di atas $1(\mathrm{~N}>1)$.

Aspek yang paling dominan pada manfaat yang didapatkan oleh pengunjung museum terdapat pada meningkatnya apresiasi sejarah (84\%) setelah melakukan kunjungan. Hal ini menunjukkan bahwa museum telah berhasil mengemas keberadaan sejarah sehingga dapat dipahami oleh pengunjung yang datang. Berikutnya adalah pada aspek kemenarikan produk (74\%), kenyamanan museum $(73 \%)$, dan kejelasan informasi yang diberikan (70\%) sebagai aspek-aspek yang dianggap cukup bermanfaat oleh pengunjung. 


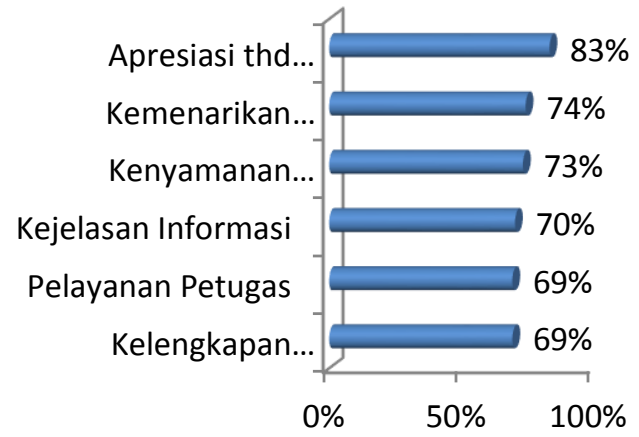

GAMBAR 2

\section{PERSEPSI GENERASI Y TERHADAP NILAI (BENEFIT) MENGUNJUNGI MUSEUM}

Khusus pada aspek pelayanan petugas dan kelengkatapn produk memiliki nilai di bawah $70 \%$, hal ini menunjukkan bahwa kedua aspek ini perlu untuk ditingkatkan kinerjanya. Pelayanan petugas memiliki peran penting karena berpengaruh pada penyampaian jasa dan informasi tentang museum. Adapun kelengkapan produk lebih ditekankan pada penyediaan fasilitas penunjang yang dapat digunakan untuk meningkatkan manfaat kunjungan ke museum.

Persepsi pengunjung tentang korbanan yang dikeluarkan pada saat mengunjungi museum berada pada nilai rata-rata skor $63 \%$. Pada dasarnya, pengunjung merasa bahwa uang atau korbanan finansial yang dikeluarkan untuk mengunjungi museum relatif tidak memberatkan, sebaliknya perasaan yang dialami, energi, dan waktu yang dikeluarkan oleh pengunjung museum dianggap memberatkan. Hal ini ditunjukkan melalui gambar berikut ini:

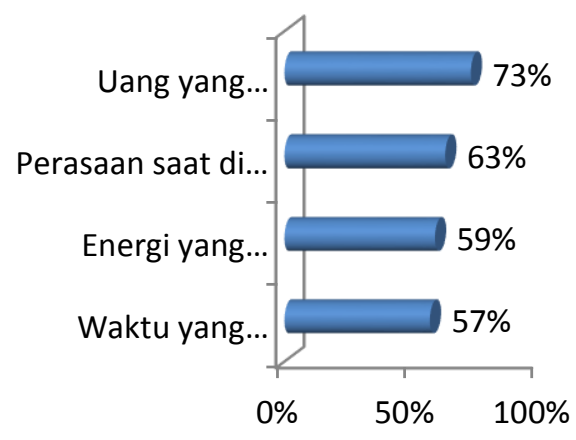

GAMBAR 3

PERSEPSI GENERASI Y TERHADAP KORBANAN (COST) DALAM MENGUNJUNGI MUSEUM
Data mengimplikasikan bahwa pengunjung merasakan bahwa korbanan yang bersifat psikologis lebih besar dibandingkan korbanan yang bersifat finansial karena biaya masuk ke museum (aspek finansial) tergolong relatif cukup terjangkau sehingga tidak memberatkan pengunjung. Korbanan psikologis yang dianggap memberatkan bisa diartikan bahwa pengunjung merasa "terpaksa" untuk datang ke museum, misalnya dengan alasan untuk menyelesaikan tugas dari sekolah. Kondisi ini perlu mendapatkan perhatian oleh pengelola museum, utamanya agar mereka mendapatkan pengalaman yang lebih menyenangkan ketika berkunjung ke museum.

\subsubsection{Keunikan}

Salah satu dasar yang diterapkan oleh museum agar menarik untuk dikunjungi adalah dengan memamerkan dan menonjolkan keunikan yang dimiliki. Sumber keunikan tersebut berasal dari produk atau koleksi museum, keunikan desain bangunan (eksterior), desain interior, serta tata letak dalam memamerkan koleksi museum. Data menunjukkan bahwa persepsi pengunjung tentang keunikan museum terletak pada keunikan produk atau koleksi yang dipamerkan oleh museum. Hasil dirangkum dalam gambar berikut ini:

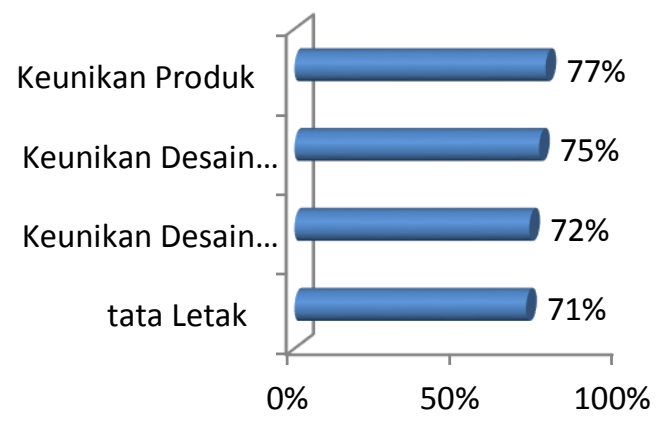

GAMBAR 4

PERSEPSI GENERASI Y TERHADAP KEUNIKAN MUSEUM

Data menunjukkan bahwa keunikan produk atau koleksi museum berada pada peringkat pertama, keunikan desain eksterior pada peringkat kedua, berikutnya adalah keunikan desain interior, dan tata letaknya. Deskripsi data ini mengimplikasikan bahwa daya tarik utama museum terletak pada keunikan produk atau koleksi yang dipamerkan. Namun demikian unsur eksterior atau desain bangunan yang tampak dari luar juga perlu diperhatikan karena pengunjung cukup tertarik pada aspek ini. 


\subsubsection{Kredibilitas}

Strategi positioning berikutnya adalah tentang cara suatu organisasi untuk menempatkan produk atau jasa yang dihasilkan melalui kredibilitas yang dimiliki. Kredibilitas museum terletak pada apakah informasi yang diberikan dipercaya oleh pengunjung dan seberapa jauh tingkat kepercayaan pengunjung terhadap otensitas atau keaslian dari koleksi yang dimiliki oleh museum.

Berkaitan dengan hal tersebut, hasil penelitian menunjukkan bahwa tingkat kepercayaan pengunjung berada pada kategori "sedang" yaitu nilai skor sebesar 74\% - 75\%. Hasilnya tersaji pada gambar berikut ini:

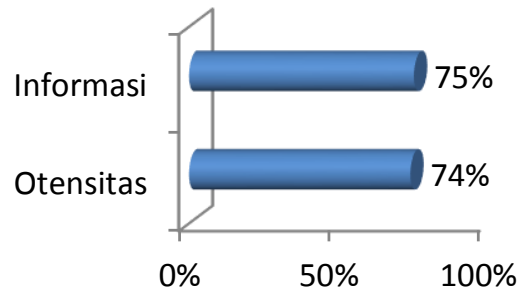

GAMBAR 5

PERSEPSI GENERASI Y TERHADAP KREDIBILITAS MUSEUM

Data menunjukkan bahwa informasi dan otensitas koleksi museum yang cukup dipercaya oleh pengunjung dan harus semakin ditingkatkan. Salah satu faktor yang menyebabkan kredibilitas museum masih tergolong dalam kategori "sedang" adalah karena sarana interpretasi yang diberikan masih kurang. Interpretasi yang diberikan tidak hanya yang bersifat tertulis, namun intepretasi yang diberikan secara langsung oleh pemandu wisata lokal (perseonnel) di museum.

\subsubsection{Keberlanjutan}

Aspek lain yang diperhatikan dalam melakukan strategi positioning adalah mengenai keberlanjutan (sustainablity) atau tingkat kepastian suatu organisasi dalam menumbuh kembangkan produk dan jasa di masa yang akan datang. Hasil penelitian menunjukkan bahwa pengunjung berharap, bahwa di masa yang akan datang museum dapat meningkatkan media informasi melalui penambahan sarana dan prasarana yang lebih beragam. Hal ini konsisten dengan hasil yang didapat pada penelaahan sebelumnya, yaitu pada unsur kredibilitas informasi yang termasuk dalam kategori "sedang". Dengan demikian pengunjung memiliki harapan yang cukup tinggi (81\%) agar museum dapat menambah media informasi. Hal ini disajikan pada gambaran data berikut ini:

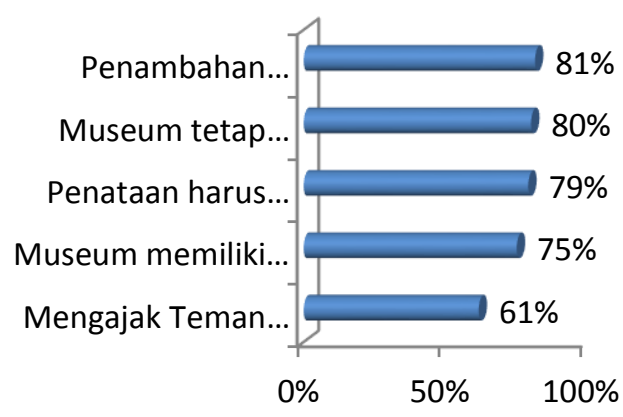

\section{GAMBAR 6 \\ PERSEPSI GENERASI Y TERHADAP KEBERLANJUTAN MUSEUM}

Data juga menunjukkan bahwa pengunjung berharap agar museum tetap buka (80\%) artinya mereka mengharapkan kepastian bahwa museum dapat terus menjalankan operasinya untuk melayani kebutuhan akan pengetahuan pada masyarakat luas. Aspek lain yang perlu ditingkatkan adalah pada segi penataan, penambahan sarana web khusus, serta penambahan fasilitas yang baik sehingga mereka bersedia mengajak rekannya untuk berkunjung ke museum. Data menunjukkan aspek minat untuk mengajak rekan berkunjung ke museum di masa yang akan datang masih sangat kurang (61\%). Padahal diharapkan pengunjung yang telah datang akan melakukan kunjungan ulang ke museum bersama rekan lainnya.

\subsubsection{Kesesuaian}

Aspek strategi positioning berikutnya adalah tentang kesesuaian antara yang ditawarkan dengan situasi dan kondisi yang ditemui oleh pengunjung di museum. Hasil penelitian menunjukkan bahwa tingkat kesesuaian berada pada kategori "sedang", seperti yang disajikan pada gambar berikut ini:

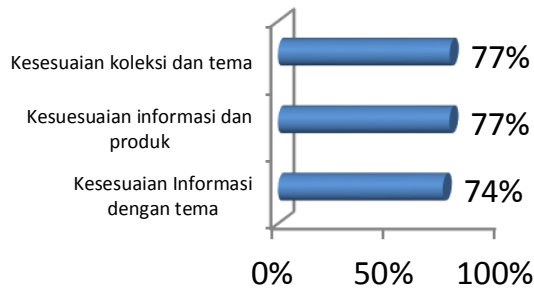

GAMBAR 7

PERSEPSI GENERASI Y TERHADAP KESESUAIAN MUSEUM 
Pengunjung beranggapan bahwa koleksi cukup menunjukkan tema museum yang dikunjungi. Tema museum dapat diketahui melalui penamaan (brand) yang terdapat pada museum. Sebagai contoh Museum Geologi mengandung tema mengenai keberadaan unsur geologi bumi, hal ini dinilai sesuai oleh pengunjung. Namun ada beberapa nama Museum yang menggunakan istilah yang tidak diketahui oleh pengunjung sebelum mereka melakukan kunjungan, sehingga hal ini mengakibatkan penilaian yangkurang. Sebelum berkunjung, mereka biasanya memiliki kesan atau pemahaman sendiri, setelah berkunjung ternyata apa yang dipikirkan sebelumnya berbeda, sehingga mereka menganggap kesesuaian koleksi dengan tema tergolong dalam kondisi yang "sedang". Aspek lain adalah kesesuaian informasi dari produk/koleksi museum dan dengan tema yang juga termasuk dalam kategori "sedang".

\subsubsection{Perbandingan Skor Antar Sub Variabel Positioning}

Apabila dibandingkan antara masingmasing aspek atau sub variabel dalam strategi positioning, maka kondisi penempatan produk dan jasa museum dalam benak pengunjung tergolong dalam kategori "sedang" karena nilai skor berada di bawah $80 \%$. Skor positioning yang tinggi terdapat pada aspek kesesuaian (76\%) sedangkan yang terendah terdapat pada aspek nilai (70\%). Seperti tersaji pada perolehan data berikut ini:

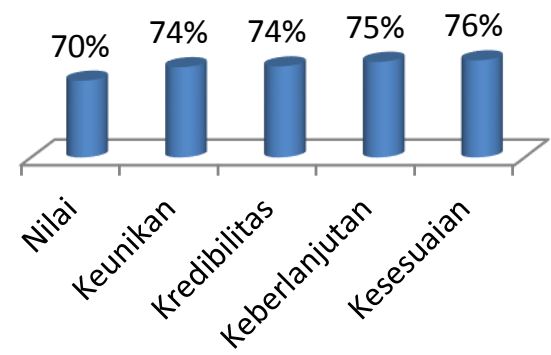

\section{GAMBAR 8 \\ PERBANDINGAN SKOR ANTAR SUB VARIABEL POSITIONING}

Hal ini menunjukkan bahwa pengelola museum belum memposisikan nilai yang unggul yang akan dirasakan jika mengunjungi museum. Nilai merupakan perbandingan dari manfaat dengan korbanan, data menunjukkan walaupun korbanan finansial yang diberikan cukup rendah, namun korbanan yang bersifat psikologis masih dirasa cukup memberatkan pengunjung untuk datang ke museum. Hal inilah yang perlu dicermati oleh para pengelola agar dapat menarik pengunjung untuk menyukai dan menikmati kunjungannya di museum.

\subsection{Keputusan Generasi Y untuk Berkunjung ke Museum}

Keputusan berkunjung ke museum, lebih banyak dilakukan karena kesadaran pengunjung untuk menambah pengetahuan $(85 \%)$, ketertarikan untuk mengunjungi museum termasuk dalam kategori "sedang" hal ini tampak dari nilai skor untuk mengunjungi museum dalam rangka menyelesaikan tugas sekolah yang berada pada posisi $76 \%$. Ditambah lagi skor untuk tertarik pada koleksi museum yang hanya mencapai 75\%. Aspek keinginan dan tindakan untuk mengunjungi museum tergolong rendah karena indikatorindikator menunjukkan nilai antara 58\% - 65\% seperti terdapat pada tabel berikut ini:

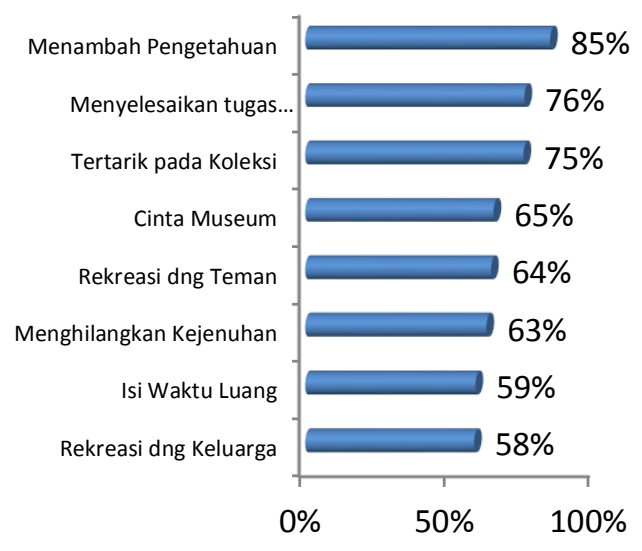

\section{GAMBAR 9 \\ DASAR KEPUTUSAN GENERASI Y UNTUK MENGUNJUNGI MUSEUM}

Hasil penelitian mengenai keputusan berkunjung ini menunjukkan bahwa tahap pengembangan museum yang ada saat ini tergolong pada tahap pengenalan karena baru menimbulkan "kesadaran" bagi pengunjung tentang keberadaan museum yang mampu menambah pengetahuannya. Namun belum sampai pada tahap tertarik, ingin, apalagi bertindak untuk mengunjungi museum tanpa ada pengaruh dari luar.

Adapun rekapitulasi hasil penilaian tersebut terdapat pada gambar berikut ini: 


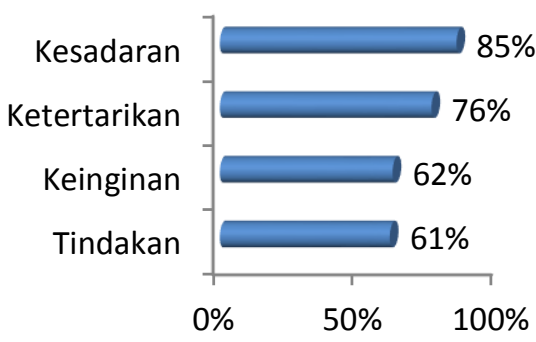

GAMBAR 10

REKAPITULASI PENILAIAN

TERHADAP SUB VARIABLE KEPUTUSAN BERKUNJUNG

Hasil tersebut menunjukkan bahwa, selama ini pengunjung museum yang berasal dari Generasi Y atau yang berusia 15 - 19 tahun, mau datang ke museum kalau ada tugas atau program dari sekolah. Keinginan untuk mengunjungi museum dalam rangka mengisi waktu luang atau sekedar berlibur dengan teman dan keluarga masih terbilang kurang. Jadi, walaupun sudah mengetahui dan sadar akan manfaat untuk mengunjungi museum, namun beum disertai dengan tindakan nyata untuk datang ke museum.

\subsection{Pengaruh Strategi Positioning terhadap \\ Keputusan Berwisata Edukasi ke Museum pada Generasi Y}

Setelah membahas hasil penelitian yang bersifat deskriptif atau situasi dan kondisi yang ada, penelitian ini juga melakukan pengujian terhadap paradigma penelitian. Penelitian yang bersifat verifikatif berfungsi untuk mengetahui besar pengaruh strategi positioning (variabel $\mathrm{X}$ ) dan sub variabel (Variabel X1, X2, X3, X4, $\mathrm{X} 5)$ mana yang memiliki pengaruh yang paling signifikan terhadap keputusan berwisata edukasi (variabel Y).

Variabel strategi positioningterdiri dari 5 (lima) sub variabel (dimensi), yaitu: nilai (X1), keunikan (X2), kredibilitas (X3), keberlanjutan (X4), dan kesesuaian (X5). Perhitungan koefisien jalur pengaruh variabel strategi positioningyang terdiri dari 5 (lima) dimensi, yaitu: nilai (X1), keunikan (X2), kredibilitas (X3), keberlanjutan (X4), dan kesesuaian (X5)terhadap keputusan berwisata edukasi ke museum (Y) disajikan pada gambar berikut ini:

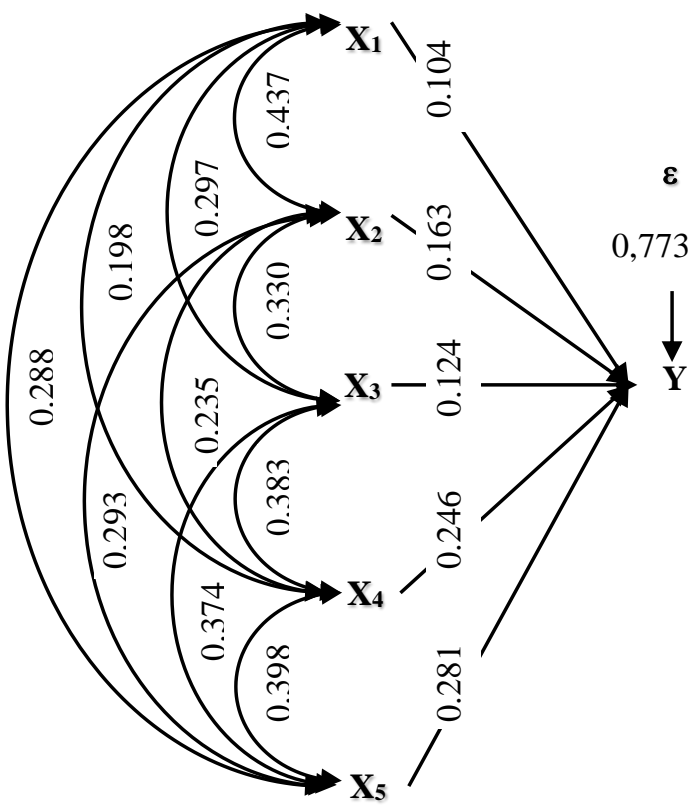

$$
\begin{aligned}
& \text { GAMBAR } 11 \\
& \text { DIAGRAM JALUR HIPOTESIS } \\
& \text { PENGARUH STRATEGI POSITIONING } \\
& \text { TERHADAP KEPUTUSAN BERWISATA } \\
& \text { EDUKASI } \\
& \text { Untuk menentukan penerimaan atau } \\
& \text { penolakan hipotesis } \mathrm{H}_{\mathrm{o}} \text {, baik menggunakan } \\
& \text { pengujian signifikansi koefisien korelasi } \\
& \text { maupun uji-t, maka digunakan Tabel berikut: }
\end{aligned}
$$

TABEL 1

HASIL PENGUJIAN HIPOTESIS PENGARUH VARIABEL STRATEGI POSITIONINGYANG TERDIRI DARI 5 (LIMA) DIMENSI, YAITU : NILAI (X1), KEUNIKAN (X2), KREDIBILITAS (X3), KEBERLANJUTAN (X4), DAN KESESUAIAN (X5)TERHADAP KEPUTUSAN BERWISATA EDUKASI (Y)

\begin{tabular}{|c|c|c|c|c|c|}
\hline $\begin{array}{c}\text { Pengaruh } \\
\text { Variabel }\end{array}$ & $\begin{array}{c}\text { Koefisien } \\
\text { Jalur }\end{array}$ & $\mathrm{t}_{\text {hitung }}$ & $\mathrm{t}_{\text {tabel }}$ & Sig & $\begin{array}{c}\text { Pengujian } \\
\text { Hipotesis }\end{array}$ \\
\hline $\mathrm{X}_{1}$ terhadap Y & 0.104 & 2.029 & 1,960 & 0.043 & $\mathrm{H}_{0}$ Ditolak \\
\hline $\mathrm{X}_{2}$ terhadap Y & 0.163 & 3.135 & 1,960 & 0.002 & $\mathrm{H}_{0}$ Ditolak \\
\hline $\mathrm{X}_{3}$ terhadap Y & 0,124 & 2.381 & 1,960 & 0.018 & $\mathrm{H}_{0}$ Ditolak \\
\hline $\mathrm{X}_{4}$ terhadap Y & 0.246 & 4.814 & 1,960 & 0.000 & $\mathrm{H}_{0}$ Ditolak \\
\hline $\mathrm{X}_{5}$ terhadap Y & 0.281 & 5.402 & 1,960 & 0.000 & $\mathrm{H}_{0}$ Ditolak \\
\hline
\end{tabular}

Sumber: Hasil Pengolahan Data 2009 
Tabel di atas menunjukkan bahwa tingkat signifikansi pengaruh strategi positioningyang terdiri dari 5 (lima) dimensi, yaitu : nilai (X1), keunikan (X2), kredibilitas (X3), keberlanjutan (X4), dan kesesuaian (X5)terhadap keputusan berwisata edukasi (Y) seluruhnya memiliki nilai lebih kecil dari 0,05. Dengan demikian, maka kesimpulannya adalah bahwa Ho ditolak. Pengujian hipotesis juga dapat dilakukan dengan membandingkan nilai $\mathrm{t}_{\text {tabel }}$ dengan nilai $\mathrm{t}_{\text {hitung. }}$. Untuk $\alpha=0,05$ nilai $\mathrm{t}$ tabel adalah 1,960. Karena nilai thitung lebih besar

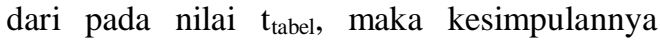
adalah bahwa Ho ditolak. Jadi kedua model pengujian tersebut, baik melalui pengujian signifikansi koefisien korelasi maupun uji-t, sama-sama menghasilkan penolakan $\mathrm{H}_{0}$.

Berdasarkan uraian di atas maka dapat disimpulkan bahwa strategi positioningyang terdiri dari 5 (lima) dimensi, yaitu : nilai (X1), keunikan (X2), kredibilitas (X3), keberlanjutan (X4), dan kesesuaian (X5)berpengaruh terhadap keputusan berwisata edukasi (Y).

Besarnya koefisien pengaruh baik langsung maupun tidak langsung serta pengaruh total strategi positioningyang terdiri dari 5 (lima) dimensi, yaitu: nilai (X1), keunikan (X2), kredibilitas (X3), keberlanjutan (X4), dan kesesuaian (X5)terhadap keputusan berwisata edukasi (Y) disajikan pada Tabel berikut.

TABEL 2

KOEFISIEN PENGARUH VARIABEL STRATEGI POSITIONINGYANG TERDIRI DARI 5 (LIMA) DIMENSI, YAITU : NILAI (X1), KEUNIKAN (X2), KREDIBILITAS (X3), KEBERLANJUTAN (X4), DAN KESESUAIAN (X5)TERHADAP KEPUTUSAN BERWISATA EDUKASI (Y)

\begin{tabular}{|c|c|c|c|c|c|c|c|}
\hline \multirow[b]{2}{*}{ Dimensi } & \multicolumn{6}{|c|}{ Pengaruh } & \multirow[b]{2}{*}{$\begin{array}{c}\text { Pengaruh } \\
\text { Total }\end{array}$} \\
\hline & Langsung & $\begin{array}{c}\text { Tidak } \\
\text { Langsung } \\
\text { Melalui } \\
\text { X }_{1}\end{array}$ & $\begin{array}{c}\text { Tidak } \\
\text { Langsung } \\
\text { Melalui } \\
\mathrm{X}_{2}\end{array}$ & $\begin{array}{c}\text { Tidak } \\
\text { Langsung } \\
\text { Melalui } \\
\text { X }_{3}\end{array}$ & $\begin{array}{c}\text { Tidak } \\
\text { Langsung } \\
\text { Melalui } \\
\text { X }_{4}\end{array}$ & $\begin{array}{c}\text { Tidak } \\
\text { Melalui } \\
\text { Langsung } \\
\text { X }_{5}\end{array}$ & \\
\hline $\mathrm{X}_{1}$ & 0.011 & - & 0.007 & 0.004 & 0.005 & 0.008 & 0.035 \\
\hline $\mathrm{X}_{2}$ & 0.027 & 0.007 & - & 0.007 & 0.009 & 0.013 & 0.063 \\
\hline $\mathrm{X}_{3}$ & 0.015 & 0.004 & 0.007 & - & 0.012 & 0.013 & 0.051 \\
\hline $\mathrm{X}_{4}$ & 0.061 & 0.005 & 0.009 & 0.012 & - & 0.027 & 0.114 \\
\hline $\mathrm{X}_{5}$ & 0.079 & 0.008 & 0.013 & 0.013 & 0.027 & - & 0.140 \\
\hline \multicolumn{7}{|c|}{ Pengaruh Total } & 0.403 \\
\hline
\end{tabular}

Sumber: Hasil Pengolahan Data 2009

Tabel memperlihatkan bahwa pengaruh langsung dimensi nilai terhadap keputusan berwisata edukasi adalah sebesar 0.011, pengaruh tidak langsung melalui dimensi keunikan sebesar 0,007, pengaruh tidak langsung melalui dimensi kredibilitas sebesar 0,004, pengaruh tidak langsung melalui dimensi keberlanjutan sebesar 0,005, dan pengaruh tidak langsung melalui dimensi kesesuaian sebesar 0,008. Secara keseluruhan pengaruh dimensi nilaiterhadap variabel keputusan berwisata edukasi adalah sebesar 0,035 .

Pengaruh langsung dimensi keunikan terhadap keputusan berwisata edukasi adalah sebesar 0.027, pengaruh tidak langsung melalui dimensi nilai sebesar 0,007, pengaruh tidak langsung melalui dimensi kredibilitas sebesar 0,007, pengaruh tidak langsung melalui dimensi keberlanjutan sebesar 0,009, dan pengaruh tidak langsung melalui dimensi kesesuaian sebesar 0,013. Secara keseluruhan pengaruh dimensi keunikanterhadap variabel keputusan berwisata edukasi adalah sebesar 0,063 .

Pengaruh langsung dimensi kredibilitas terhadap keputusan berwisata edukasi adalah sebesar 0.015, pengaruh tidak langsung melalui dimensi nilai sebesar 0,004, pengaruh tidak langsung melalui dimensi keunikan sebesar 0,007, pengaruh tidak langsung melalui dimensi keberlanjutan sebesar 0,012, dan pengaruh tidak langsung melalui dimensi kesesuaian sebesar 0,013. Secara keseluruhan pengaruh dimensi kredibilitas terhadap variabel keputusan berwisata edukasi adalah sebesar 0,051.

Pengaruh langsung dimensi keberlanjutan terhadap keputusan berwisata edukasi adalah sebesar 0.061, pengaruh tidak langsung melalui dimensi nilai sebesar 0,005, pengaruh tidak langsung melalui dimensi keunikan sebesar 0,009, pengaruh tidak langsung melalui dimensi kredibilitas sebesar 0,012, dan pengaruh tidak langsung melalui dimensi kesesuaian sebesar 0,027. Secara 
keseluruhan pengaruh dimensi keberlanjutan terhadap variabel keputusan berwisata edukasi adalah sebesar 0,114 .

Pengaruh langsung dimensi kesesuaian terhadap keputusan berwisata edukasi adalah sebesar 0.079 , pengaruh tidak langsung melalui dimensi nilai sebesar 0,008, pengaruh tidak langsung melalui dimensi keunikan sebesar 0,013, pengaruh tidak langsung melalui dimensi kredibilitas sebesar 0,013, dan pengaruh tidak langsung melalui dimensi keberlanjutan sebesar 0,027. Secara keseluruhan pengaruh dimensi kesesuaian terhadap variabel keputusan berwisata edukasi adalah sebesar 0,140 .

Dengan menjumlahkan total pengaruh masing-masing dimensi, maka dapat diketahui besarnya total pengaruh variabel strategy positioning terhadap variabel keputusan berwisata edukasi yaitu sebesar 0,403.

Perhitungan koefisien jalur dimensi lainnya diluar dimensi pembentuk variabel strategy positioning terhadap variabel keputusan berwisata edukasi adalah sebagai berikut :

$$
\begin{aligned}
P_{Z \varepsilon} & =\sqrt{1-R_{Y(X 1, X 2, X 3)}^{2}} \\
& =\sqrt{1-0,403} \\
& =0,773
\end{aligned}
$$

Hal ini mencerminkan bahwa dimensi nilai, keunikan, kredibilitas, keberlanjutan, dan kesesuaian secara bersama-sama mempengaruhi variabel kpeutusan berwisata edukasi sebesar 0,403 . Sisanya sebesar $(0,773)^{2}$ $=0,597$ merupakan pengaruh dimensi lain yang tidak termasuk ke dalam variabel penelitian.

\subsection{Pembahasan}

Positioning daya tarik wisata adalah cara pandang wisatawan terhadap produk pariwisata yang ditawarkan. "Product position is the way the product is defined by consumers on important attributes - the place the product occupies in consumer's mind relative to competing products" (Kotler, 2006:179). Dalam rangka menempatkan suatu produk atau layanan tertentu dalam benak konsumen tersebut, pengelola perlu untuk memperhatikan beberapa faktor yang meliputi: nilai, keunikan, kredibilitas, keberlanjutan, dan kesesuaian produk dan jasa yang ditawarkan pada wisatawan. Faktor-faktor tersebut, selanjutnya membuat produk dan jasa yang ditawarkan berada pada benak wisatawan untuk selanjutnya menstimulasi keinginannya untuk mengunjungi daya tarik wisata tersebut. Adapun untuk mengubah keinginan menjadi suatu bentuk keputusan berkunjung ke suatu daya tarik wisata perlu diperhatikan faktor yang meliputi: kesadaran, ketertarikan, keinginan, dan tindakan dari pengunjung.

Hasil penelitian menunjukkan bahwa secara deskriptif terungkap bahwa kelima faktor pembentuk dalam strategi positioning berada dalam kategori "sedang", seperti terdapat pada tabel berikut ini:

\begin{tabular}{|c|c|c|c|c|}
\hline $\begin{array}{l}\text { Variabel } \\
\text { Sub Variabel }\end{array}$ & Skor & $\begin{array}{l}\text { Skor } \\
\text { Ideal }\end{array}$ & Prosentase & Keterangan \\
\hline \multicolumn{5}{|l|}{$\begin{array}{l}\text { Strategi } \\
\text { Positioning }\end{array}$} \\
\hline Nilai & 1055 & 1500 & $70 \%$ & Sedang \\
\hline Keunikan & 1109 & 1500 & $74 \%$ & Sedang \\
\hline Kredibilitas & 1112 & 1500 & $74 \%$ & Sedang \\
\hline Keberlanjutan & 1130 & 1500 & $75 \%$ & Sedang \\
\hline Kesesuaian & 1136 & 1500 & $76 \%$ & Sedang \\
\hline \multicolumn{5}{|l|}{$\begin{array}{l}\text { Keputusan } \\
\text { Berkunjung }\end{array}$} \\
\hline Kesadaran & 1275 & 1,500 & $85 \%$ & $\begin{array}{l}\text { Sangat } \\
\text { Tinggi }\end{array}$ \\
\hline Ketertarikan & 1140 & 1,500 & $76 \%$ & Sedang \\
\hline Keinginan & 930 & 1,500 & $62 \%$ & Kurang \\
\hline Tindakan & 915 & 1,500 & $61 \%$ & Kurang \\
\hline
\end{tabular}

TABEL 3

REKAPITULASI SKOR VARIABEL

Hasil penelitian tersebut menunjukkan bahwa upaya dalam pengelolaan museum untuk menempatkan produk dan layanan kepada pengunjung yang tergolong di segmen Generasi Y belum maksimal. Kegiatan untuk untuk berkunjung secara mandiri masih belum dilakukan oleh segmen Generasi Y, secara ratarata mereka bersedia mengunjungi museum apabila diminta oleh sekolah. Hal ini menunjukkan bahwa fungsi museum belum sepenuhnya dirasakan oleh pengunjung, terutama fungsi "enjoyment", adapun yang berkaitan dengan fungsi "edukasi" dan "apresiasi budaya" sudah cukup baik dirasakan oleh pengunjung. Fungsi "enjoyment"dapatmembentuknilai tambah (value added) yang dapat dimasukan dalam strategi positioning sehingga diharapkan museum dapat lebih menarik untuk dikunjungi oleh Generasi Y.

Salah satu pembentuk "enjoyment" yang dapat dicermati oleh pengelola museum adalah bahwa pengunjung menyukai apabila datang ke museum secara bersama-sama dengan teman. Namun, hasil penelitian 
menunjukkan bahwa tingkat manfaat museum untuk dikunjungi bersama teman-teman kurang. Hal ini juga ditegaskan oleh hasil penelitian yang menunjukkan bahwa dukungan fasilitas penunjang, misalnya keberadaan ruang publik, masih kurang. Berdasarkan hal tersebut, dapat diketahui bahwa pengunjung menginginkan ruang publik yang nyaman agar dapat berinteraksi dengan teman yang datang. Hal ini menunjukkan bahwa museum juga diharapkan memiliki fungsi sosial, utamanya untuk meningkatkan interaksi diantara pengunjung.

Dalam rangka meningkatkan fungsi sosial agar pengunjung dapat semakin menikmati museum, pengelola juga dapat berpartisipasi sebagai fasilitator yang membuka kesempatan untuk meningkatkan tumbuh dan berkembangnya komunitaskomunitas pencinta museum. Suatu komunitas biasanya terbentuk di masyarakat karena kesamaan visi, tujuan, cita-cita, hobi, dan karakter spesifik lainnya. Contohnya adalah komunitas penggemar sejarah Bandung, seperti Bandung Heritage, Bandung Trails, Mahanagari, dan Aku Cinta Museum adalah kelompok beranggotakan masyarakat dari latar belakang yang berbeda. Kunjungan yang dilakukan ke museum biasanya dilakukan untuk semakin mengapresiasi kebudayaan dan sejarah yang terdapat di museum sekaligus sebagai media interaksi sosial untuk para anggotanya, termasuk diantaranya adalah anggota yang berasal pada segmen generasi $\mathrm{Y}$. Oleh sebab itu, musuem juga diharapkan memiliki ruang publik agar dapat menambah kualitas interaksi sosial diantara pengunjung sehingga mereka dapat lebih memaknai keberadaan museum.

Adapun hasil uji verifikatif pada penelitian ini menunjukkan bahwa faktor "keberlanjutan" menjadi aspek yang memiliki nilai pengaruh yang paling tinggi dibandingkan keempat faktor lain dalam strategi positioning. Hal ini menunjukkan bahwa untuk meningkatkan keputusan untuk berkunjung dalam berwisata edukasi, perlu ditanamkan kepada pengunjung bahwa museum akan terus berupaya untuk berkembang sesuai dengan tuntutan zaman. Walaupun koleksi yang dipamerkan di museum di Kota Bandung, sangat kental terhadap benda-benda peninggalan sejarah dan masa lalu, namun pengemasan dan teknik komunikasi dan interpretasi benda-benda tersebut diharapkan dapat berorientasi masa depan. Dengan demikian, diharapkan pengunjung menjadi lebih tertarik untuk datang ke museum di Kota Bandung.

Faktor yang memiliki nilai uji paling rendah adalah dari segi "nilai" atau perbandingan antara manfaat dengan korbanan yang dikeluarkan oleh pengunjung. Hasil uji verifikatif ini sejalan dengan hasil analisa deskriptif yang menunjukan bahwa skor "nilai" lebih rendah dibandingkan dengan lainnya. Ini perlu diperhatikan oleh pengelola atraksi wisata edukasi, terutama museum, utamanya agar museum dapat mengemas produk dan jasa yang dimiliki sehingga memiliki nilai tambah (value added) bagi setiap pengunjung yang datang.

\section{KESIMPULAN DAN REKOMENDASI} 5.1 Kesimpulan

Wisatawan atau Pengunjung pada Segmen Generasi Y menganggap bahwa keberadaan museum di Kota Bandung cukup menarik. Hal ini tampak pada penilaian mayoritas pengunjung yang mengaggap bahwa kesan terhadap museum sebagai tempat yang menarik untuk dikunjungi. Adapun museum yang paling sering dikunjungi adalah Museum Geologi, Museum KAA, dan Museum Sri Baduga. Penilaian pengunjung terhadap unsur "sejarah" dalam museum tergolong sangat tinggi. Hal ini menunjukkan positioning yang kuat dari museum sebagai daya tarik wisata sejarah di Kota Bandung. Adapun kondisi yang dinilai kurang baik untuk museum adalah aspek tempat, yaitu bangunan eksterior dan interior serta fasilitas penunjang museum.

Aspek yang sangat dominan pada strategi positioning museum adalah mengenai "keberlanjutan" yang menekankan pada harapan bahwa museum dapat lebih maju untuk terus menyediakan informasi yang dibutuhkan. Aspek yang kurang dilakukan oleh museum adalah pada segi "nilai". Hal inilah yang perlu dicermati oleh para pengelola agar dapat menarik pengunjung untuk menyukai dan menikmati kunjungannya di museum.

Pengunjung Generasi $\mathrm{Y}$ sangat menyadari arti penting museum, namun belum sampai pada tahap berkunjung ke museum secara langsung. Dengan kata lain, kesadaran belum dibarengi dengan tindakan nyata, yaitu berkunjung langsung ke museum secara mandiri.

Strategi positioning memilikipengaruh yang signifikan dalam memicu keputusan wisatawan untuk berkunjung ke museum. 


\subsection{Rekomendasi}

Hasil penelitian menunjukkan bahwa strategi positioning museum dengan menguatkan fungsi museum dengan menonjolkan nilai, keunikan, kredibilitas, keberlanjutan, dan kesesuaian agar museum dapat meningkatkan pengalaman pengunjung sehingga mereka dapat memperoleh manfaat kunjungannya secara optimal.

Salah satu bentuk komunikasi dalam museum adalah interpretasi atau menafsirkan koleksi museum sehingga pengunjung dapat lebih memaknai kunjungan yang dilakukan. Moscardo (2000) menyatakan bahwa interpretasi merupakan segala aktivitas yang bertujuan untuk menjelaskan kepada pengunjung tentang tingkat kepentingan suatu obyek, budaya, atau tempat. Interpretasi, menurutnya, memiliki tiga fungsi utama yaitu untuk meningkatkan pengalaman pengunjung, meningkatkan pengetahuan dan pemahaman pengunung, serta meningkatkan kesadaran pengunjung untuk berpartisipasi dalam proteksi dan konservasi suatu tempat atau kebudayaan tertentu. Interpretasi tidak hanya dilakukan dengan membangun sarana dan prasarana yang menyediakan informasi tentang museum dan koleksi yang terkandung didalamnya, namun juga kepada personel atau karyawan yang menjelaskan dan memberikan informasi kepada publik.

Dalam pengelolaan museum, terdapat dua hal yang harus dipertimbangkan untuk menguatkan fungsi museum, yaitu bagaimana mengelola aset berwujud, yang selanjutnya disebut dengan hard system management dan mengelola aset bersifat lunak, yang selanjutnya disebut dengan soft system management.

Pengelolaan aset berwujud (hard)merupakan kemampuan untuk mengelola koleksi museum, fasilitas pendukung yang ada di dalamnya, serta pengelolaan ruang untuk pameran. Adapun aset yang bersifat lunak (soft)meliputi kegiatan pengorganisasian dan administrasi museum, strategi edukasi (termasuk didalamnya pengembangan interpretasi kepada pengunjung), serta strategi pemasaran.

Dalam kaitannya dengan upaya memposisikan museum agar menarik untuk dikunjungi, maka program yang diajukan untuk dikemas dalam sistem manajemen yang bersifat hard dan soft, adalah sebagai berikut:

\section{Berkelanjutan:}

Program ini bertujuan untuk meningkatkan pemahaman kepada pengunjung bahwa museum akan terus berupaya untuk mengembangkan diri dan mengikuti perkembangan informasi, teknologi, dan komunikasi untuk melayani pengunjung. Kegiatan yang dilakukan meliputi:

- Pengembangan fasilitas pendukung, khususnya sarana informasi dan interpretasi yang bersifat audio visual.

- Pengembangan fasilitas ruang publik dan ruang sosial yang lebih luas dan nyaman

- Memfasilitasi tumbuhnya jaringan sosial untuk mencintai museum melalui komunitas-komunitas pencinta museum.

- Memasukan kunjungan ke museum sebagai bagian dari kurikulum pelajar SMP dan SMA.

\section{Kesesuaian:}

Program ini bertujuan untuk meningkatkan pemahaman pengunjung sehingga memiliki pengetahuan yang lebih mendalam mengenai museum dan koleksi yang terkandung didalamnya.

Kegiatan yang dilakukan adalah sebagai berikut:

- Pengembangan media interpretasi di dalam museum.

- Pemuktahiran data dan informasi mengenai informasi yang berkaitan dengan koleksi dan kegiatan yang berlangsung di museum pada situs internet

\section{Kredibilitas}

Program ini bertujuan untuk meningkatkan kepercayaan pengunjung terhadap produk dan layanan museum yang dapat ditingkatkan melalui optimalisasi layanan yang diberikan oleh personel atau SDM didalam museum. Kegiatan yang dilakukan adalah sebagai berikut:

- Peningkatan kompetensi personnel museum untuk meningkatkan kualitas dalam memberikan informasi.

\section{Keunikan}

Program ini bertujuan untuk menonjolkan keunikan yang terdapat di dalam museum sehingga pengunjung tertarik untuk datang ke museum. Upaya untuk menonjolkan keunikan museum ini dapat dilakukan dengan cara memilih media yang sesuai sehingga informasi tentang keunikan museum dapat diakses oleh pengunjung/calon pengunjung.

- Peningkatan publikasi mengenai koleksi museum untuk menunjukkan keunikan museum melalui brosur dan pemberitaan di majalah-majalah sekolah. 


\section{Nilai}

Program ini bertujuan untuk memberikan nilai tambah (value added) sehingga pengunjung yang datang akan merasakan manfaat yang lebih besar dibandingkan dengan korbanan yang dilakukan. Kegiatan yang dilakukan, misalnya:

- Penambahan fasilitas pendukung untuk memfasilitasi kegiatan sosial berupa ruang publik yang nyaman agar museum semakin diminati oleh kaum muda sebagai media bersosialisasi. Hal ini akan memberikan nilai tambah bagi museum sehingga ia tidak hanya berperan sebagai media penambah pengetahuan melainkan juga memiliki manfaat sosial yang menyediakan ruang publik untuk bersosialisasi.

Penelitian ini masih memiliki banyak keterbatasan, untuk penelitian selanjutnya, disarankaan agar dapat mengembangkan penelitian yang berhubungan dengan identifikasi nilai tambah (value added) dalam produk dan layanan museum serta metode penciptaan nilai (value creation) agar dapat meningkatkan kunjungan ke museum.

\section{DAFTAR PUSTAKA}

Bernardi, C. (2005). The strategic development of museums: a system dynamics approach. Diambil pada 10 Maret 2008, dari www. neumann.hec.ca/aimac2005/PDF_Text/ Bernardi_Chiara.pdf

DiMaggio, P.J. (1986). Can culture survive the marketplace? In P.J. DiMaggio (Eds), Nonprofit enterprise in the arts: Studies in mission and constraint. Oxford: Oxford University Press.

Gilmore, A., and Rentschler, R. (2002). Changes in museum management: A custodial or marketing emphasis? Journal of Management Development, 21(10), 745-760.

Goulding, C. (2000). The museum environment and the visitor experience. European Journal of Marketing, 34(3/4), 261-278.

Grant, I. and O'Donohoe, S. (2007). Why young consumers are not open to mobile marketing communication. International Journal of Advertising, 26(2), 223-246.

Hawkey, R. (2004). Learning with digital technologies in museums, science centers and galleries. Retrieved March 10, 2008, from http://www.futurelab.org.uk/resources/
documents/lit_reviews/Museums_Galle ries_Review.pdf

Hume, Margee \& Gillian Sullivan Mort. 2008. Enhancing The Experience: Creating Service Opportunities Using Mobile Phone Technology In Museums. London Journal of Tourism, Sport and Creative Industries (LJTSCI), Volume 1, Edition 2, Autumn 2008: 3-20

Kotler, N. (2003). Creativity and interactivity: New ways to experience, market and manage museums. Diambil pada bulan Maret 20, 2008, dari http://www.fuel4arts.com/files/attach/ NeilKotler_Museums0404031.pdf

Kotler, P., and Kotler, N. (1998). Museum strategy and marketing: Designing missions, building audiences, generating revenue and resources. San Francisco: Jossey Bass Wiley.

Malhotra, Nareshk. 2004. Marketing Research and Applied Orientation. $4^{\text {th }}$ Ed. Prentice Hall Intl., Inc.

Malhotra, Naresh K. 2002. Basic Marketing Research: Applications to Contemporary Issues. International Edition. Pearson Education, Inc.:Upper Saddle River, New Jersey.

McCrindle, M. (2007). Understanding generation- $Y$. Diambil Pada bulan March 10, 2008, dari http://www.learningtolearn.sa.edu.au/C olleagues/files/links/UnderstandingGen Y.pdf

McLean, F. (1994). Services marketing: The case of museums. The Service Industries Journal, 14(2), 190-203.

Museums Australia (2007). What is a museum? Diambil pada 20 Maret 2008, dari http://www.museumsaustralia.org.au/si te/page13.php

Newsome,David; Susan A. Moore and Ross K. Dowling.(2002). Aspects of Tourism: Natural Area Tourism: Ecology, Impacts and Management. Cromwell Press. Inggris

Pierroux, P. (1998). Art in networks: Information and communication technology in art museums. University of Oslo: The Department of Art History.

Rice, R. and Hancock, L. (2005). The mall intercept: A social norms marketing research tool. The Report on Social Norms, 4(7) 4-7.

Robbins, J.E., and Robbins, S.S. (1981). Museum marketing: Identification of high, moderate, and low attendee 
segments. Academy of Marketing

Science Journal, 9(1/2), 66-76.

Rust, R.T., and Kannan, P.K. (2003). Eservice: a new paradigm for business in the electronic environment. Communications of the ACM, 46(6), 3742.

Seybold, P.B. (1998). Customers.com: How to create a profitable business strategy for the Internet and beyond. New York: Crown Business.

Seybold, P.B. (2001). The Customer Revolution: How to thrive when customers are in control. New York: Crown Business.

Sindell, K. (2000). Loyalty marketing for the internet age: How to identify, attract, serve, and retain customers in an $e$ commerce environment. Chicago: Dearborn Financial Publishing.

Sugiyono. 2006. Metode Penenlitian Bisnis. Alfabeta: Bandung.

Suharsimi Arikunto. 2006. Prosedur Penelitian Suatu Pendekatan Praktis. Bina Aksara: Yogyakarta

Temporal, P \& Tritt M. 2001. Roman and Customer Maximizing Brand Value Trough Powerfull Relationship Management. Jhon Wiley \& Sons (asia) pte ltd: Singapore

Tjiptono, Fandy. 2002. Manajemen Jasa. Andi: Yogyakarta.

Uzzi, B. (1997). Social structure and competition in interfirm networks: The paradox of embeddedness. Administrative Science Quarterly, 42(1), 35-67.

Uzzi, B. and Gillespie, J.J. (2002). Knowledge spillover in corporate financing networks: embeddedness and the firm's debt performance. Strategic Management Journal, 23(7), 595-618.

Weerawardena, J., and Sullivan Mort, G. (2006). Investigating social entrepreneurship: A multidimensional model. Journal of World Business, 41(1), 21-35.

Yeh, J., and Lin, C. (2005). Museum marketing and strategy: Directors' perception and belief. Journal of the American Academy of Business, 6(2), 279-284.

Yoeti, Oka A. 2008. Perencanaan dan Pengembangan Pariwisata. Pradnya Paramita: Jakarta.

Zemke, R and Connellan, T. (2001). E-service: 24 ways to keep your customers - when the competition is just a click away. New York: McGraw-Hill. 
Vanessa Gaffar 